RESEARCH ARTICLE

\title{
Delineating an Unmarked Graveyard by High-Resolution GPR and pXRF Prospection: The Medieval Church Site of Furulund in Norway
}

\author{
Rebecca J. S. Cannell*, Lars Gustavsen ${ }^{\dagger}$, Monica Kristiansen ${ }^{\dagger}$ and Erich $\mathrm{Nau}^{\dagger}$
}

The lack of accurate locational information on abandoned medieval and later graveyards constitutes a considerable challenge to national and local bodies tasked with their protection and management. These sites are increasingly in danger of destruction due to climatic changes, intensified farming schemes or developmental encroachment, and there is an ever-growing need to develop nonintrusive methods to ensure their detection and delineation so that they can be protected. In 2014, the Norwegian Directorate for Cultural Heritage received alarming information on the worsening state of the medieval church site at Furulund, in the southeast of the country. A successful, cost-effective campaign using high-resolution, large-scale georadar surveys in conjunction with geochemical mapping using portable XRF was undertaken in order to delineate and characterise the graveyard so that remedial actions could be initiated and the graveyard protected. Whilst the interpretations are unique to the site, the method combination has the potential to effectively resolve detection and protection of other, similar sites in Norway and beyond.

Keywords: portable XRF; ground-penetrating radar; graveyard; Norway

\section{Introduction}

Abandoned medieval church sites in Norway tend to lead a fairly anonymous existence. However, in 2014 the Norwegian Directorate for Cultural Heritage and Hedmark County Council received alarming information on the state of the church site at Furulund, some $15 \mathrm{~km}$ north of the town of Kongsvinger (Figure 1). Human skeletal remains had started surfacing as a result of ploughing, and there were concerns that the graveyard was rapidly being decimated. A subsequent site visit confirmed that the site had seen substantial erosion and that remedial action was urgently needed. The Directorate therefore sought advice from the Norwegian Institute for Cultural Heritage Research (NIKU) on how to map the church site by way of non-intrusive methods. Two methods were proposed and ultimately employed; preliminary geochemical sampling and analysis using portable Xray fluorescence (pXRF) followed by highresolution groundpenetrating radar (GPR) surveys. The aim of this paper is to illustrate how the complementary non-intrusive techniques can record archaeological features, place them in their environmental setting, assess the damage and provide sufficient information for protection strategies. To have wider relevance to archaeology, methods, approaches and

\footnotetext{
* University of Oslo, NO

Norwegian Institute for Cultural Heritage Research, NO

Corresponding author: Rebecca Cannell

(rebecca.cannell@iakh.uio.no)
}

results have to be contextually evaluated, and therefore this article also sets the medieval cemetery site in what is known of its archaeological and historical context, and its current position in cultural heritage management.

Reactive archaeology is often a reality for reasons of resources, need and capacity. However, when the aim is preservation in-situ over preservation by record via excavation, such as in the case of the large number of medieval graveyards in Norway, there is a need for a costeffective, non-destructive approach. Unmarked medieval graveyards constitute a considerable challenge for the governmental bodies tasked with their protection and management, and the researchers for whom these sites constitute a valuable source of information. In Norway, up to 2,000 graveyards are believed to have existed in the Middle Ages. Of these, 647 are still in use, while a further 614 are securely attested in historical sources, but are now recorded as abandoned. The remainder are simply hinted at in toponymical and folkloric sources (Brendalsmo \& Eriksson 2015). The unmarked graveyards are often found in presently cultivated fields, and more often than not, accurate locational information is lacking. Although protected by the Norwegian Cultural Heritage Act, this renders these vulnerable sites inadequately maintained and threatened by continual natural processes, agricultural activities or intentional and unintentional acts of destruction. The need to accurately locate and delimit such sites is therefore imperative both from a research and management point of view. Given the 


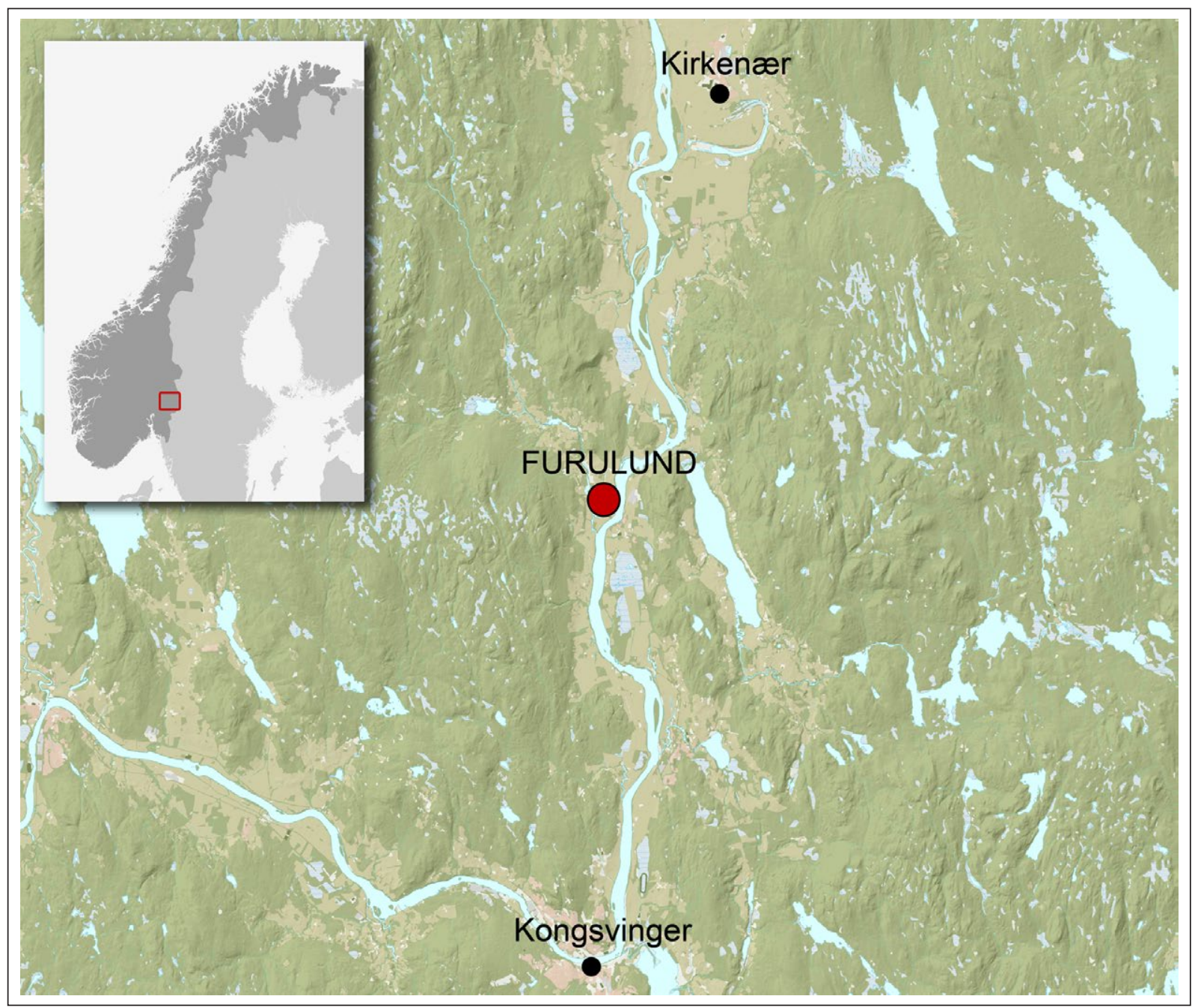

Figure 1: Furulund is situated on the western banks of the River Glomma, between the town of Kongsvinger and the village of Kirkenær in Hedmark County.

Map source: The Norwegian Mapping Authority, Geovekst and Municipalities, 2018.

large number of potential sites, however, their mapping by way of intrusive methods is deemed unfeasible on account of the costs involved. In light of this, geophysical and geochemical methods present themselves as advantageous, both in terms of cost-efficiency and their non-destructive nature.

\section{The Church Site and its Setting \\ Natural setting}

The site is surrounded by arable fields and forests at the base of an alluvial valley, some $120 \mathrm{~m}$ from the current course of the River Glomma, a large, mature lowland river. The site is situated on top of a gentle slope caused by an older natural levee on the river's western bank, 8 $\mathrm{m}$ above present water levels (Figure 2). The prevailing soils and sediments consist of alluvial silts (NGU 2017), which have formed fluvic soils, with a typical fine to coarse silt texture and a low proportion of fine sands within the laminated structure. The soils are classified as Endostagnic Fluvic Cambisols on the site and the immediate surroundings, changing to Fluvic Cambisols further afield (NIBIO 2017). Common in fluvial sediments where new flood events regularly deposit new sediment, Cambisols are young, poorly developed soils with weak structural development. The poorly drained property (endostagnic) is most apparent immediately east of the church site, where the levee slopes fairly sharply down to a small, linear depression. This was noticeably wetter, with a far higher organic content in the plough soil, suggesting consistently poorer drainage and colluvial inputs. As the river course comprises frequent meanders, oxbow lakes and palaeochannels, the site could easily sit beside such a feature, with peaty, poorly draining soils. Additionally, its close proximity to the river will cause a high water table, especially in periods of high discharge, such as spring.

\section{Historical background}

Because of their location, rural medieval graveyards in Norway are seldom subject to archaeological investigations and, indeed, none have been investigated in their entirety. The character of their layout and of the graves themselves must therefore draw on evidence from studies of graveyards still in use, on excavations in urban contexts, medieval law texts and recorded tradition. Graveyards were always located next to a church, in an area delineated by a ditch or a simple fence, and usually measuring c. $30 \times 30$ m (Brendalsmo 2014: 78). Within this area shallow, rectangular graves were 


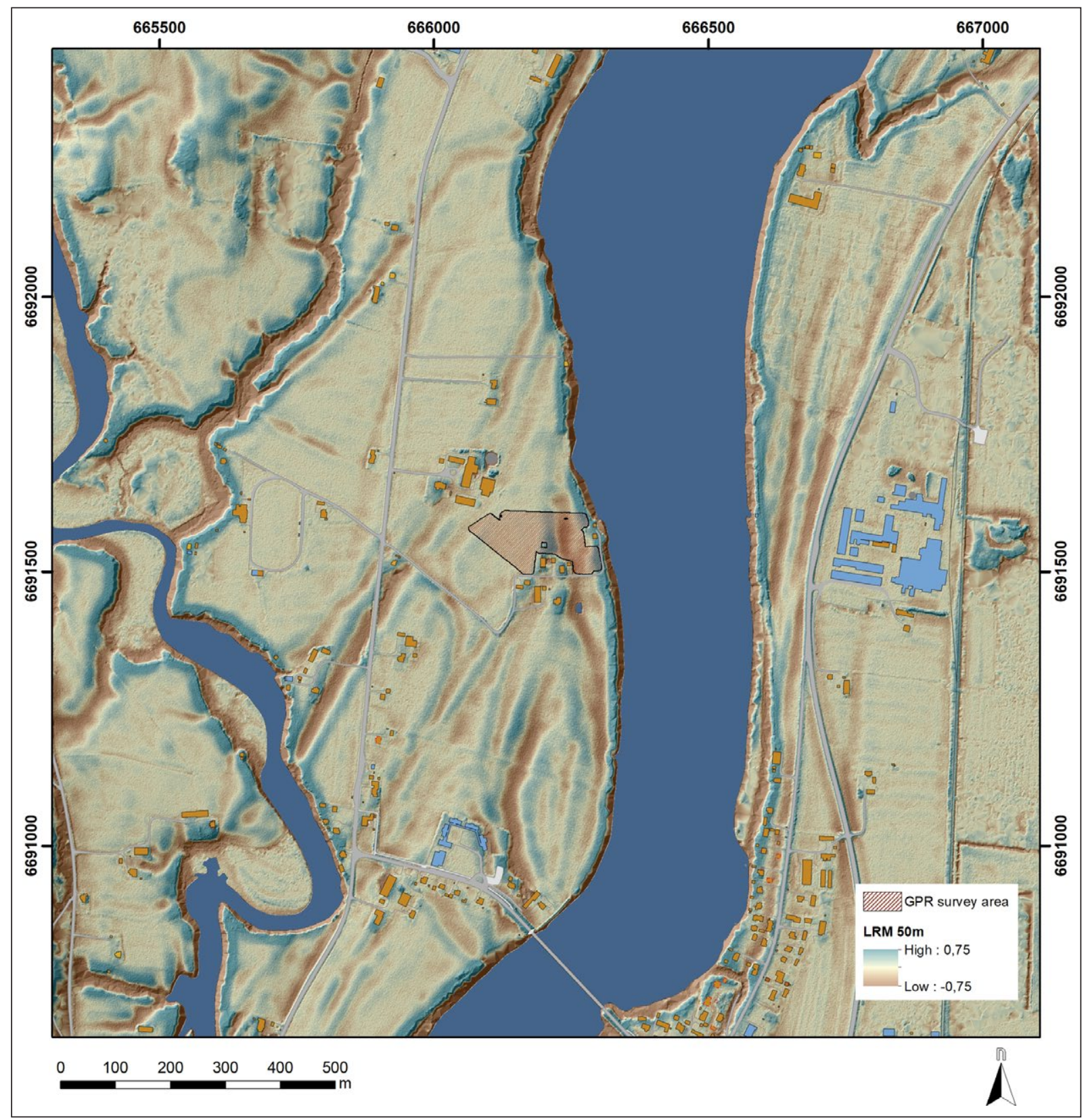

Figure 2: ALS derived DTM of the survey site and its surroundings. The survey site is located on the western bank of the River Glomma. The tributary Agnåa can be seen to the west, with numerous palaeochannels and terraces beside the current river beds.

Map source: The Norwegian Mapping Authority, Geovekst and Municipalities, 2018.

dug, usually disregarding the presence of older graves. The graves themselves were orientated east - west according to Christian convention and the deceased may have been interred in rectangular or trapezoidal wooden coffins, or in a simple linen shroud (Brendalsmo 1989: 27). Divisions within the graveyard were strictly governed by social standing and sex. More affluent individuals were buried closer to the church building than the less privileged, and women were buried to the south of the church and men to the north. Divisions based on geographic affiliation, where individual hamlets were assigned discrete plots have also been noted (Brendalsmo 2014: 81).

Little is known with certainty about the church that once served the small community at Furulund. Judging from a surviving limestone baptismal font, it predates the year 1200, and written sources inform us that it was in use until 1648, when it was considered too dilapidated for further upkeep, and consequently torn down. Furulund is briefly mentioned in a handful of written sources between the $14^{\text {th }}$ and $17^{\text {th }}$ centuries, which provide clues as to the status and, arguably, the physical size of the church. The medieval cadastres and urbariums in which the church figures, record that only a nominal tax was paid every year to the bishop and the Diocese (Brendalsmo 2015: 7). Later sources indicate that service was only held once per month. From the few written sources available, therefore, it seems the building at Furulund constituted a small rural church of modest, but perhaps not uncommon standing.

No systematic archaeological investigations have been carried out in order to locate the church or its graveyard. Map regression studies indicate that the areas surrounding the site were forested at least until the early 
$19^{\text {th }}$ century, before they were converted to the arable land we see today. At this point the deterioration of the site must have started to accelerate, as intensive ploughing aerates and erodes topsoil and also incorporates subsoil, with the consequence of truncating and degrading buried archaeology. Unsupervised investigations by amateur metal detectorists in the 1980s recovered nails and tacks believed to stem from the church. Their distribution pattern formed a rough square which was thought to represent the original extent of the building, and this particular area has been demarcated by the landowner by retaining a small section of unploughed land in the field, measuring approximately $10 \times 10 \mathrm{~m}$. Rather than protecting the site, however, this has had the unfortunate effect of increasing the damage to the surrounding soil as turning the plough repeatedly along the island edges has caused intensified erosion of both topsoil and subsoil. According to local informants, human bones were exposed during the excavation of a trench for a water pipe near the assumed location of the church. This was dug without archaeological supervision and so the exact location of the disturbed graves is unknown. Representatives from the Directorate for Cultural Heritage and Hedmark County Council have previously defined the approximate extent of the site based on available evidence, and concluded that the graveyard was roughly circular in shape, measuring some $33 \mathrm{~m}$ in width, and $36 \mathrm{~m}$ in length. Despite this approximate delineation, and the fact that the site is scheduled, it currently sees annual ploughing and therefore continual truncation.

\begin{abstract}
Methods
The choice of GPR over other geophysical methods was based on previous experiences where GPR had successfully detected inhumation graves in cemeteries, whereas the application of pXRF for cursory soil analysis was more experimental. Portable XRF has been successfully applied to a variety of archaeological settlement and production sites in Norway (Cannell 2017), but had never before been used on a mortuary site as a prospection tool. Geochemistry using pXRF was chosen on the assumption that the systematic mapping of certain elements across the church site would yield relatively enhanced values that would map differential land use, and thus delimit the graveyard. The combination of geophysics and geochemical prospection has been successful at delimiting settlement and activity areas in recent research (Fleisher \& Sulas 2015; Booth et al. 2017). In their case study, Fleisher and Sulas found the geochemical data added activity details to geophysical results, and evidenced activities in areas void of geophysical responses, thus the complementing methods provided information on the social and practical use of space.
\end{abstract}

The use of geophysical methods to detect and map graves, clandestine or otherwise, has a well-established history, and a considerable body of literature exists on the subject (e.g., Vaughan 1986; Bevan 1991; Davenport 2001; Cheetham 2005; Jones 2008). Due to its comparatively high spatial resolution and its capability to resolve smaller targets, whilst simultaneously providing depth information, GPR is generally considered the most suitable solution for mapping inhumation burials (Conyers 2006; Jones 2008; Moffat 2015). Alternative geophysical techniques such as magnetometer surveys (e.g., Linford 2004), and electromagnetic induction (e.g., Bigman 2012) have also seen some success, particularly when used in combination (Nobes 1999; Dalan, De Vore \& Clay 2010; Bigman 2014). Geophysical techniques have only recently been employed as tools for locating and mapping funerary monuments in Norway. This can largely be attributed to the introduction of the concept of high-resolution surveys, that is, surveys with a crossline resolution of $25 \mathrm{~cm}$ or less. Its use has generally been confined to prehistoric grave mounds (Trinks, Gansum \& Hinterleitner 2010; Gustavsen 2014: 262-264; Schneidhofer et al. 2017), although medieval and later graveyards have also been investigated (e.g., Solli \& Stamnes 2013; Davis et al. 2000).

Early published studies on mortuary sites using multi-element geochemical approaches, such as Keeley, Hudson and Evans (1977) and Bethell and Smith (1989), sampled graves in order to test the feasibility of identifying an inorganic chemical signature for a body. Bethell and Smith concluded that, whilst the local enhancement of certain elements could be directly associated with the presence of a body, the results were environmentally specific. This conclusion is not unique to the application of geochemistry on mortuary sites. The interplay between soil processes and the major and minor elemental enhancement from past human land use should be seen as site specific, and therefore it is the relative enhancement or depletion of certain elements that form the basis of interpretation (Oonk, Slomp \& Huisman 2009; Wilson, Davidson \& Cresser 2009; Vyncke et al. 2011). In Norway, single and multielement archaeological geochemistry has largely seen use on settlement sites, where it has been used to delimit areas of activity and to determine settlement morphology (Provan 1971; Provan 1973; Bakkevig 1980; Prøsch-Danielsen 1996; Prøsch-Danielsen 2005; Cannell 2017). The application to mortuary sites, however, is more limited. Within a rescue archaeology setting, the E18 Project conducted excavations of an extensive burial mound cemetery at Gulli in Vestfold County in 2005. A total of 1850 phosphate samples were taken from the topsoil over selected areas of the cemetery, but upon excavation the data from the phosphate mapping was difficult to ascribe to the documented archaeological features (Gjerpe \& Samdal 2005). Similar conclusions were reached at the Ormen Lange Project in Møre og Romsdal County in 2003, where phosphate samples were extracted from a Neolithic grave (Åstveit 2008: 272-274).

X-ray fluorescence has been applied to archaeological research for over 50 years (e.g., Shackley 2011; Charlton 2013; Frahm \& Doonan 2013), although more recent technological innovation has allowed for a reduction in instrument size, to the extent where field portable and handheld instruments are widely available. The use 
of portable XRF on soils is relatively new, especially in archaeology. It has been used for some years for environmental monitoring (e.g., Kalnicky \& Singhvi 2001; Berger, Zou \& Schliecher 2009; Photos-Jones \& Hall 2011; Ulmanu et al. 2011; Parsons et al. 2012), but it is still experimental to some degree and the instrument methodologically contested (e.g., Speakman \& Shackley 2013). That said, it is rapidly becoming established as an efficient and effective means of analysing for multiple elements to parts per million (ppm) accuracy with minimal sample preparation. This is corroborated by a rapidly increasing volume of published studies using the instrument on archaeological soils and sediments (e.g., Donais \& George 2012; Gauss et al. 2013; Hayes 2013; Grattan et al. 2014; Bissett \& Claassen 2016; Booth et al. 2017).

\section{Geochemical sampling}

Geochemical sampling had to be achieved in a minimally intrusive, cost-effective manner. Using an Eijkelkamp windowed soil auger, $3 \mathrm{~cm}$ in diameter, the base of the plough soil was sampled, taking samples at regular intervals in transects through the area. The auger was pushed 25-30 cm into the plough soil (the average topsoil depth), and removed. A sample from the base of the plough soil was then extracted using single-use plastic equipment to reduce cross-contamination. The auger was then cleaned before the next sample was taken. Using transects allowed a greater areal coverage, with a focus upon the potential limits of the site rather than the centre.

A total of five transects were initially established over the area, with samples spaced $5 \mathrm{~m}$ along the transect lines, the large distance between samples necessary to keep to a restricted budget. Further sample points were subsequently added, in order to verify trends observed in the initial analyses, bringing the total number of samples covering the assumed location of the graveyard to 61 (Figure 3). The sampling was carried out in November 2014 in cold, dry conditions.

Sampling occurred in the topsoil only, a layer that is regularly disturbed by ploughing and therefore no longer considered in-situ archaeological remains. The sampling, therefore does not directly disturb archaeology, although this could be deemed minimally intrusive over nonintrusive. More intrusively, two additional, deeper cores were taken approximately $100 \mathrm{~m}$ north and $50 \mathrm{~m}$ west of the main survey area, well away from any protected archaeological remains. Here the auger was hammered 1 $m$ into the subsoil in order to determine soil structure and development, and to sample for background elemental values. Samples were taken from all identified master soil horizons (Ap, B, C).

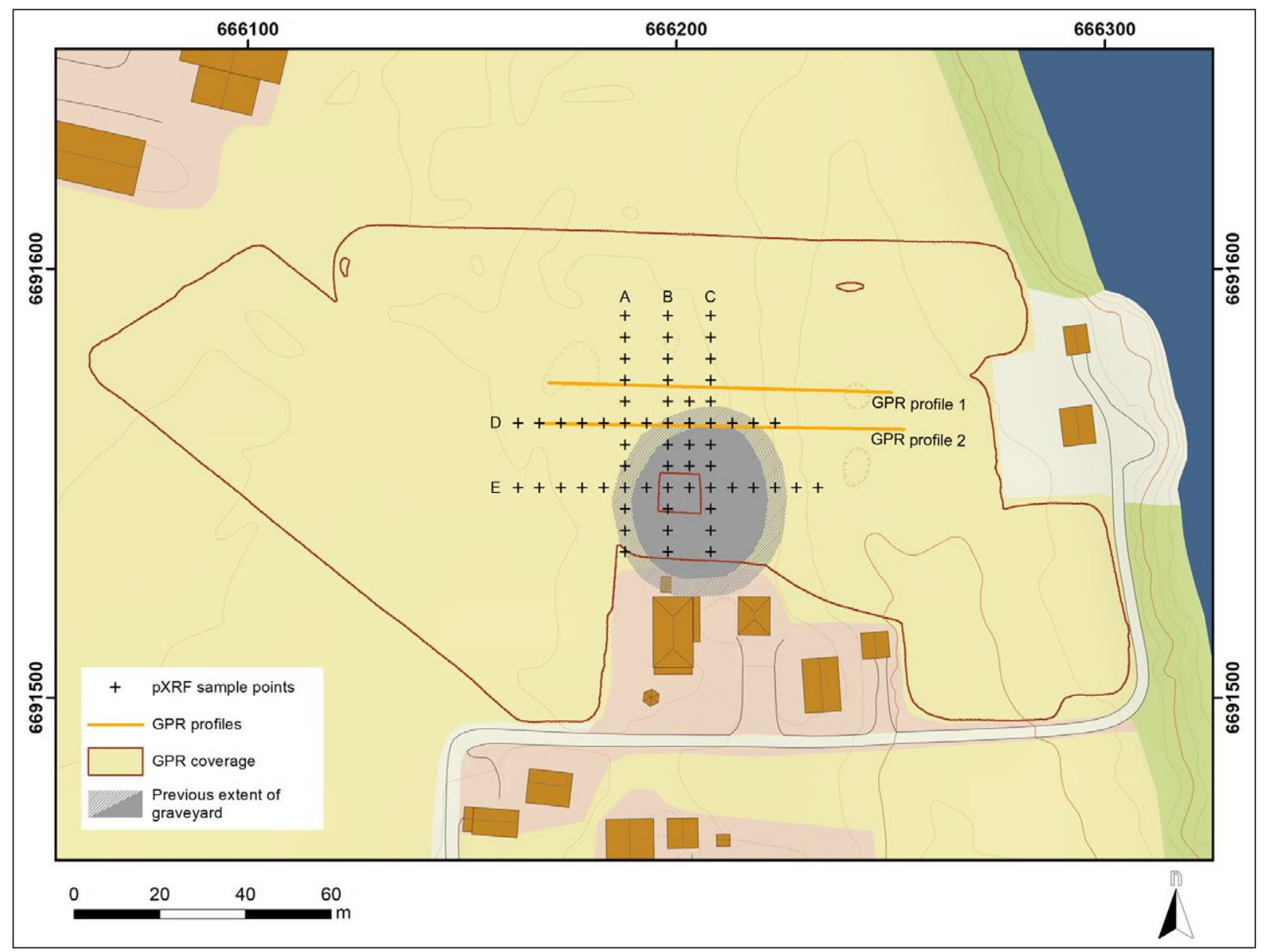

Figure 3: GPR survey area, GPR profile lines and pXRF sample points at Furulund. The GPR area encompasses approx.

1.8 hectares. The pXRF samples were taken in five main transects across the site.

Map source: The Norwegian Mapping Authority, Geovekst and Municipalities, 2018. 
In-situ analysis is of course possible with pXRF, however for lighter elements including $\mathrm{P}$, this can produce unrepresentative data due to moisture effects, issues of surface geometry, and variable distances between the sample and the instrument exacerbating issues of signal attenuation. Such analysis is purely qualitative and cannot be reproduced. Analysis was therefore conducted on processed samples in the laboratory to produce more interpretable data. Analysis typically requires 10-20 g of dried soil, so the initial samples from the site were sub-sampled. In order to remove the negative effects of moisture on sample results (Bastos, Melquiades \& Biasi 2012; Coronel et al. 2014; Schneider et al. 2016), all samples were dried at $105^{\circ} \mathrm{C}$ for 24 hours. As the soils at Furulund were well-sorted silts, sieving was not deemed necessary. After homogenising the sample, they were then placed in clean plastic sample cups with a $6 \mu \mathrm{m}$ polypropylene window. Analysis was undertaken using a Thermo Scientific Niton $\square$ XLt3 GOLDD portable XRF in mining mode, resting on a stand to ensure constant distance between the sample and the instrument. The instrument can measure the elements $\mathrm{Mg}$ to $\mathrm{Pb}$ (and above, but not relevant for this study), with a resolution down to $10 \mathrm{ppm}$, depending on the element's atomic weight. The analytical time totalled 300 seconds between all filters (50 seconds for the main filter, 100 seconds for the high, 50 for the low and 100 for the light). These settings are considered optimal for the lighter elements of interest, without taking the extra step of using helium in the pXRF (Cannell 2017). Prior to each sample run and at regular intervals, a blank sample, followed by purchased, matrix matched international standards were analysed. These were NIST 2711a, NIST 1646a, SigmaAldrich trace metals clay 2 and Sigma-Aldrich trace metals loamy clay 2 . These are suitably similar in elemental range and matrix to allow the calibration of results and between them covered all of the relevant elements. The instrument limits of detection (LOD) were set to $2 \sigma$. The calibrated values for the selected elements were imported into a geographical information system where interpolated and gridded surfaces representing trends in the values were generated using ordinary kriging. These were then combined with other data sources for further analysis.

\section{Ground-penetrating radar}

The GPR survey was conducted in October 2015 following two weeks of increasingly cold $\left(\right.$ c. $\left.12-0^{\circ} \mathrm{C}\right)$, and unusually dry (0-0.2 mm precipitation) weather. An area of 1.8 hectares was surveyed using a motorized 16-channel, $400 \mathrm{MHz}$ MALA Imaging Radar Array (MIRA) from MALA Geoscience, covering the assumed churchyard and considerable areas to the east, west and north of this. The channel spacing was $10.5 \mathrm{~cm}$ and the measurements were GPS-triggered at a rate of $50 \mathrm{~Hz}$, resulting in an inline resolution of approximately $5 \mathrm{~cm}$, depending on the driving speed. Ideally, elongated targets such as inhumation graves should be surveyed so that the survey lines cross the targets perpendicularly, as this will increase the likelihood of imaging and defining the targets (Moffat
2015: 46). Surveys of Christian cemeteries and graveyards, therefore, should be carried out in a north-south direction. At Furulund this was not an option as, although compacted and reasonably levelled, the surface still bore signs of the previous spring's ploughing in the form of narrow, east-west running ridges and troughs.

Once collected, the data were processed using the ApRadar software, developed by ZAMG ArcheoProspections $₫ / \mathrm{LBI}$ ArchPro. Here, trace interpolation, time-zero corrections, band-pass frequency filtering, spike removal, de-wow filters, average-trace-removal, amplitude-gain corrections, amplitude balancing and Hilbert transformations were applied. Time-to-depth conversion was based on hyperbola fitting and set to a velocity of $10 \mathrm{~cm} / \mathrm{ns}$ for the upper parts of the dataset, down to $10 \mathrm{~ns}$, whilst decreasing to $8 \mathrm{~cm} / \mathrm{ns}$ at $20 \mathrm{~ns}$ and beyond. The data were then resampled to a resolution of $8 \times 8 \mathrm{~cm}$, and subsequently interpolated into a 3D data block from which georeferenced depth slices of $5 \mathrm{~cm}$ thickness were generated. Visualisation, analyses and interpretation of the depth slices was performed in ArcGIS, and subsequently combined with the pXRF and additional data sources.

\section{Results}

\section{Ground-penetrating radar}

Extending well beyond the assumed boundaries of the church site, the GPR data enables a tentative characterisation of the site's former and present natural setting. To the east of the church site, on the slope towards the river, the dataset is characterised by substantial and sharply defined interconnected areas with reflecting and absorbing properties. The areas follow the slope closely, and provide a good indication of where the plough causes mechanical erosion of the site, as it cuts into and truncates the natural stratigraphy. In the western part of the site an extensive feature containing interleaving absorbing and reflecting material, can be observed. Crossing the site diagonally from the southwest towards the northeast, this feature likely represents an infilled palaeochannel, comparable to those observed in the vicinity in aerial LiDAR data (Figure 4).

Scattered in the area west of the graveyard are a series of anomalies of varying sizes and shapes, but invariably decreasing in extent with depth. Their fills appear homogeneous with absorbing properties, and they are clearly defined against the more reflective subsoil background. Because of their diverging appearance, and the fact that they do not form any clear geometric patterns, the anomalies have been interpreted as tree throws formed by the mechanical removal of vegetation in the area, as it was converted to arable land. The eastern part of the site is characterised by a considerable number of drainage ditches and modern pipes. None of these appear to have disturbed the graveyard significantly, bar a single ditch diagonally crossing the area in the south-eastern corner. A north-south running ditch and pipe skirts the eastern extent of the graveyard, narrowly missing the burials.

In the GPR data a cluster of anomalies interpreted as graves has been identified immediately north of the present villa and gardens (Figure 5). The anomalies have 


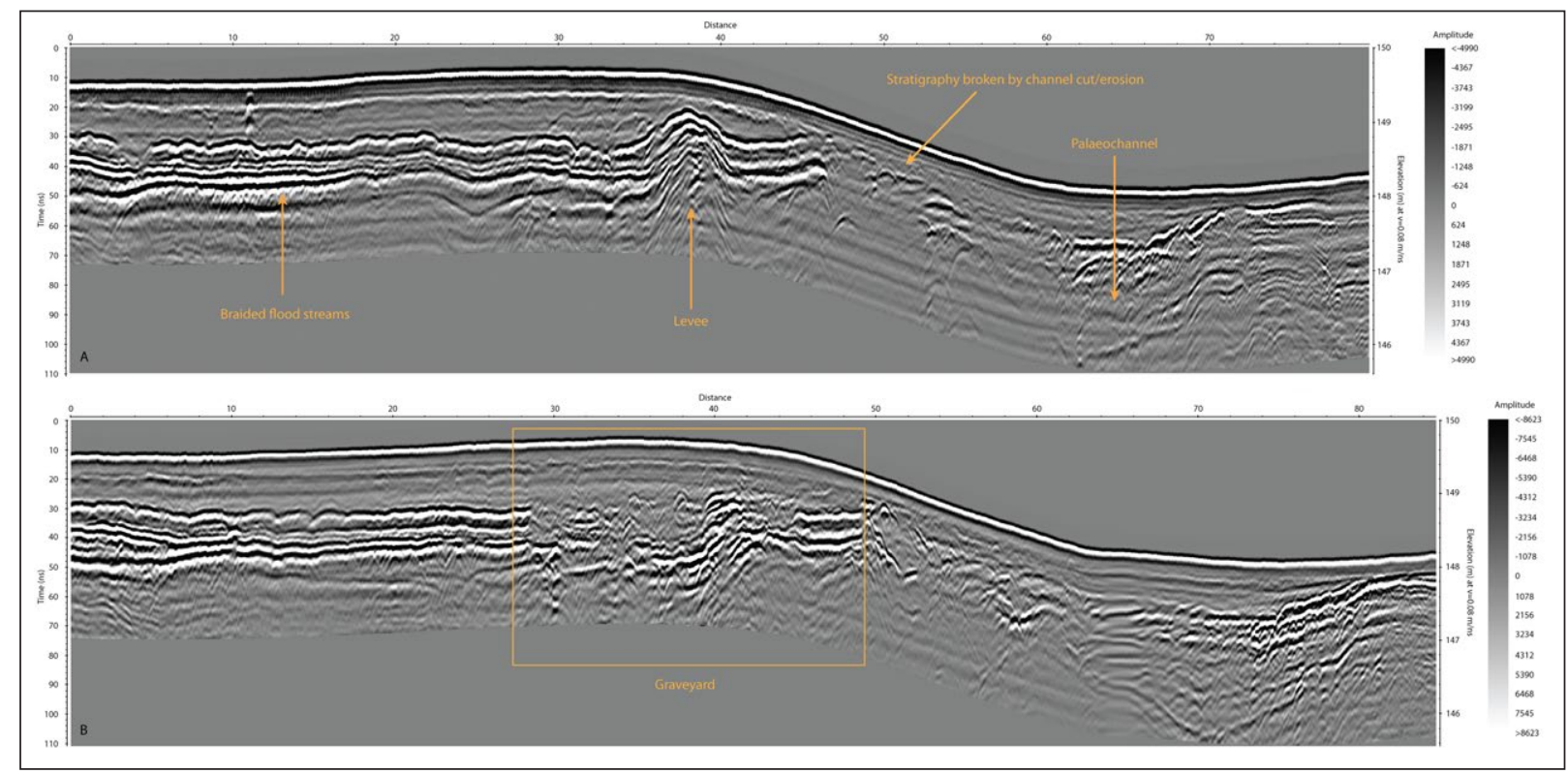

Figure 4: A: GPR profile 1, running across the area north of the graveyard and showing the natural stratigraphy of the area. B: GPR profile 2, running across the graveyard, indicating that the graves are cutting the natural stratigraphy see Figure 3 for the profiles' position in relation to the graveyard.

attenuating properties and intermittently form a strong contrast to the surrounding, highly reflective subsoil. Covering this is a fairly homogeneous deposit with attenuating properties, where no archaeological features can be observed. The features interpreted as graves start appearing in the datasets as a more or less continuous, rectangular cluster at a depth of c. $60-80 \mathrm{~cm}$ below the surface, and individual features only become identifiable at a depth of c. $100 \mathrm{~cm}$, before disappearing at c. $160 \mathrm{~cm}$ below the surface. The cluster is poorly defined against the surrounding background to the east, on the brink of the slope towards the river. Furthermore, due to their tight spacing or even intercutting, a secure delineation of individual graves is difficult. Those features that can be positively identified as graves are rectangular to subrectangular in plan. They measure between $80-250 \mathrm{~cm}$ in length, and $35-80 \mathrm{~cm}$ in width, and are orientated $\mathrm{E}-\mathrm{W}$. Because of the level of intercutting, it is difficult to determine the graves' individual depths, but for the singular graves around the edges of the graveyard, it is estimated to c. $40 \mathrm{~cm}$. All told, a total of 130 individual graves have been identified, 84 of which have been classified as 'certain', the remaining 46 classified as 'possible'. The features form a rectangular area measuring c. $32 \times 22 \mathrm{~m}$. Its borders are clearly defined to the west and north, whereas the eastern limits are less pronounced due to erosion and the southern limits obscured by the present day gardens.

\section{Geochemical Prospection}

Of the 34 elements measured, 17 were selected for calibration. These elements are those that, from previous published studies, have produced interpretable data relating to previous human activity (Entwistle, Abrahams \& Dodgshon 1998; Middleton 2004; Wilson, Davidson \& Cresser 2009; Vyncke et al. 2011). Whilst some elements
Table 1: Descriptive statistics for each element for all 61 sample points.

\begin{tabular}{lrrrr} 
& \multicolumn{1}{c}{$\mathbf{c u}$} & \multicolumn{1}{c}{$\mathbf{F e}$} & $\mathbf{C a}$ & \multicolumn{1}{c}{$\mathbf{P}$} \\
\hline Maximum & 204.130 & 30510.740 & 7287.790 & 1778.630 \\
Minimum & 0.000 & 22333.910 & 5361.330 & 647.800 \\
Mean & 14.418 & 25854.613 & 6100.688 & 1175.210 \\
Median & 0.000 & 25866.190 & 6064.720 & 1122.090 \\
Standard Deviation & 32.174 & 1767.643 & 430.554 & 258.104 \\
Kurtosis & 19.949 & -0.064 & -0.580 & -0.123 \\
Skewness & 3.896 & 0.311 & 0.247 & 0.517 \\
Range & 204.130 & 8176.830 & 1926.460 & 1130.830 \\
Count & 61.000 & 61.000 & 61.000 & 61.000
\end{tabular}

are often interpreted as specific to an activity, all relative enhancement or depletion are dependent upon local soil conditions (Cook \& Heizer 1965; Bethell \& Smith 1989; Wilson, Davidson \& Cresser 2009; Cannell 2017), therefore of these 17 , it was not assumed all would be interpreted as related to the graveyard location. In fact, only four elements could be directly related to the graveyard location; P and Ca via the enhancement of the local soils from skeletal remains and associated human activity, Fe from the changes in soil processes in the affected area, and $\mathrm{Cu}$ (Table 1). Other elements, when subject to interpolation or ordinary kriging, either spatially determined other, more recent activity, such as raised Zn by a trackway, or had no distinct spatial patterning in the sampled area. Each element $(\mathrm{Ca}, \mathrm{P}, \mathrm{Fe}$ and $\mathrm{Cu}$ ) will be briefly considered in turn below, after a short evaluation of the elements $(\mathrm{Pb}$ and $\mathrm{Sr}$ ) that were expected to be related to the graveyard, but did not produce interpretable spatial patterning. 


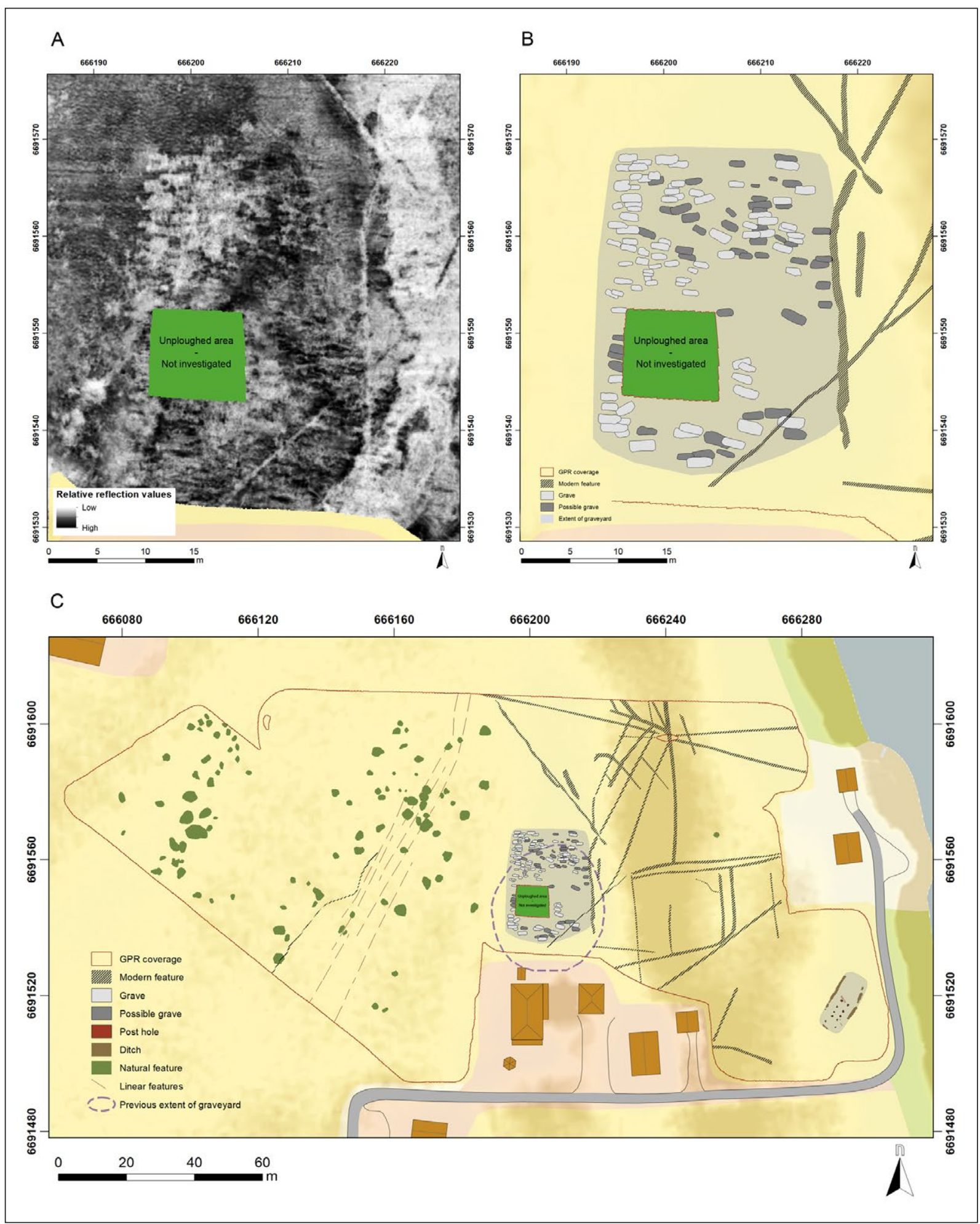

Figure 5: A: Aggregated amplitude map of the graveyard, showing depth slices between 80 and $100 \mathrm{~cm}$. B: Interpretation of the anomalies observed in the depth range 60-160 cm. C: Interpretation map of the area surrounding the graveyard.

Map source: The Norwegian Mapping Authority, Geovekst and Municipalities, 2018.

In the Middle Ages, exposure to lead via utensils, medication, pigments and personal ornaments was common, however the amount varied greatly dependent upon the location and status of the individual. Lead is primarily retained in bone; over $90 \%$ of absorbed lead is stored within the bone structure (Drasch 1982). The measured values for lead $(\mathrm{Pb})$ were low; up to $35.8 \mathrm{ppm}$. Whilst there was a slight elevation over the graveyard area, due to the inconsistency of enhancement over the area where bones were present on the surface, the data was not deemed to represent the graves. Strontium values are environmentally dependent, but as a small amount 


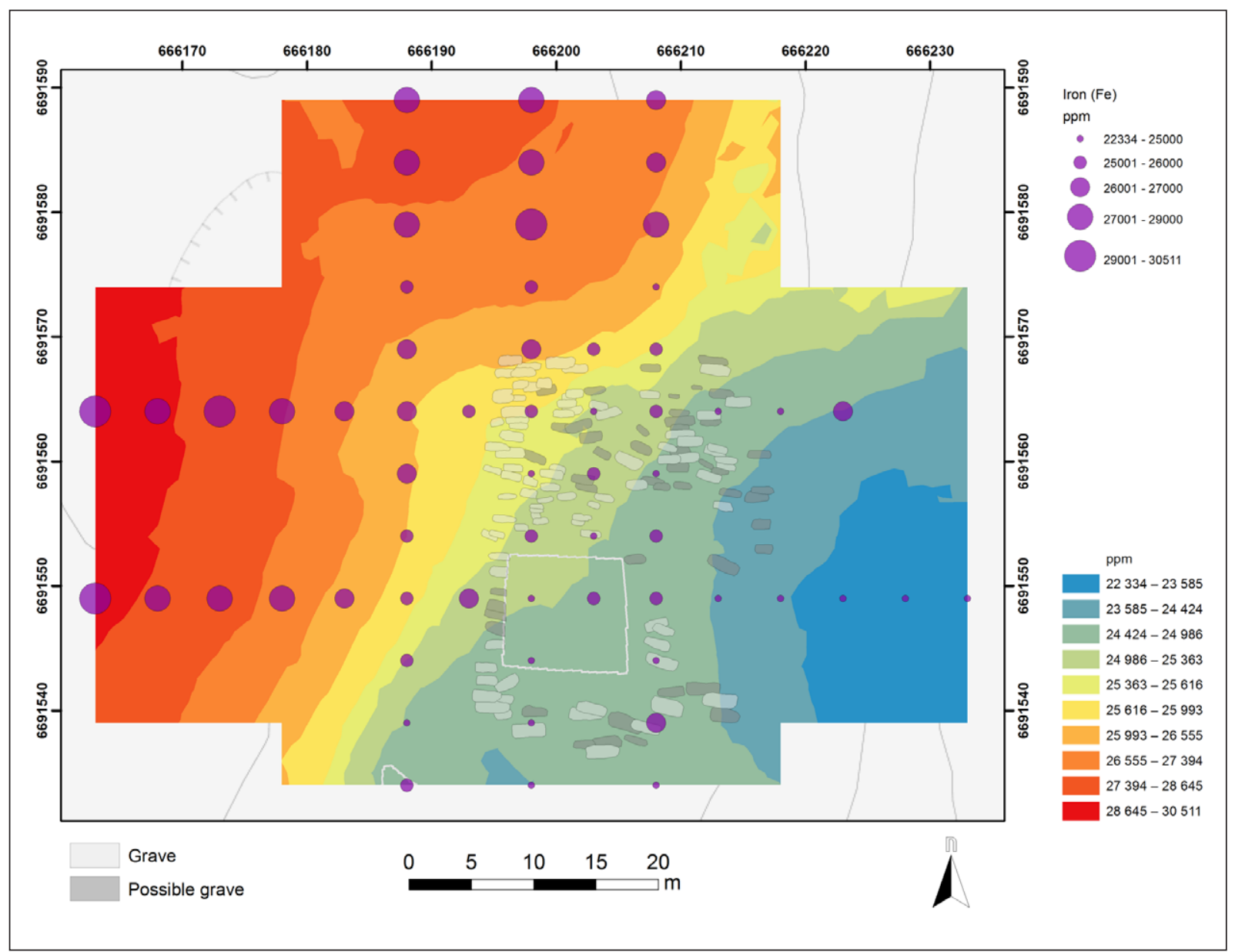

Figure 6: Interpolated distribution of Fe (ordinary kriging), with the sample points as graduated circles overlaid over the GPR interpretations.

of Sr replaces $\mathrm{Ca}$ in the bone structure (Price, Burton \& Bentley 2002), it was considered possible that Sr could be slightly enhanced by the presence of human bone. This was not the case, perhaps because the amounts taken up by humans via groundwater are very low, and environmentally dependent thus the local population reflect the local conditions without creating a reservoir effect.

The data for Fe shows a normal distribution, with values ranging from 22,333 to $30,510 \mathrm{ppm}$ within the sampled area(Figure 6). The mean of 25,272 ppm is somewhat lower than background values, which have a mean of 26,664.08 $\mathrm{ppm}$. The background values show considerable variation, from $25,525.57$ to $38,723.81 \mathrm{ppm}$, which reflects the fact that iron is both soluble in anaerobic (i.e. waterlogged) conditions, and highly variable in alluvial sediments. The distribution of $\mathrm{Fe}$ indicates a generally lower iron concentration in the graveyard area, near respecting the graves located via GPR (see below). However it is difficult to directly assign this to past activity; it potentially a result of changing drainage caused by the nearby slope to the east of the graveyard, and the impact of graves themselves on the local drainage and Fe distribution. Hence it is not a product of the graves, but perhaps an effect caused by their presence. That said, in certain soil types, relative iron depletion due to loading of the soils with organic material has been documented (Oonk et al. 2009), and this effect can be combined with the changing drainage.

Copper has repeatedly been associated with past human activity, usually in conjunction with metal working (Aston, Martin \& Jackson 1998; Cook et al. 2009; Carey et al. 2014), or as traces in certain ashes (Canti 2003). It is present in trace amounts in organic materials, including bones, and as a direct product of copper metal use. The distribution of copper at Furulund is concentrated in a well-defined $25 \times 25 \mathrm{~m}$ area, fairly central to the study area (Figure 7). Background values for $\mathrm{Cu}$ are negligible, with one exception of $22.96 \mathrm{ppm}$. Therefore, the concentration of copper centrally within the graveyard is highly likely to be from human activity. Although the values are not high - up to 204.23 ppm - the instrument has a $10 \mathrm{ppm}$ or higher resolution for $\mathrm{Cu}$. The additional samples taken over the area repeat and confirm the pattern of enhancement over the area of the graveyard where the density of graves reduces, and slightly into the denser area. Because the samples are taken from plough soils, the exact location of enhancement cannot be assumed, as some degree of movement has occurred. The effects of ploughing are assumed to be spatially limited, as discussed in Ammerman (1985) and Gustavsen et al. (2017). The exact source of the copper is unknown; however, the elevated 


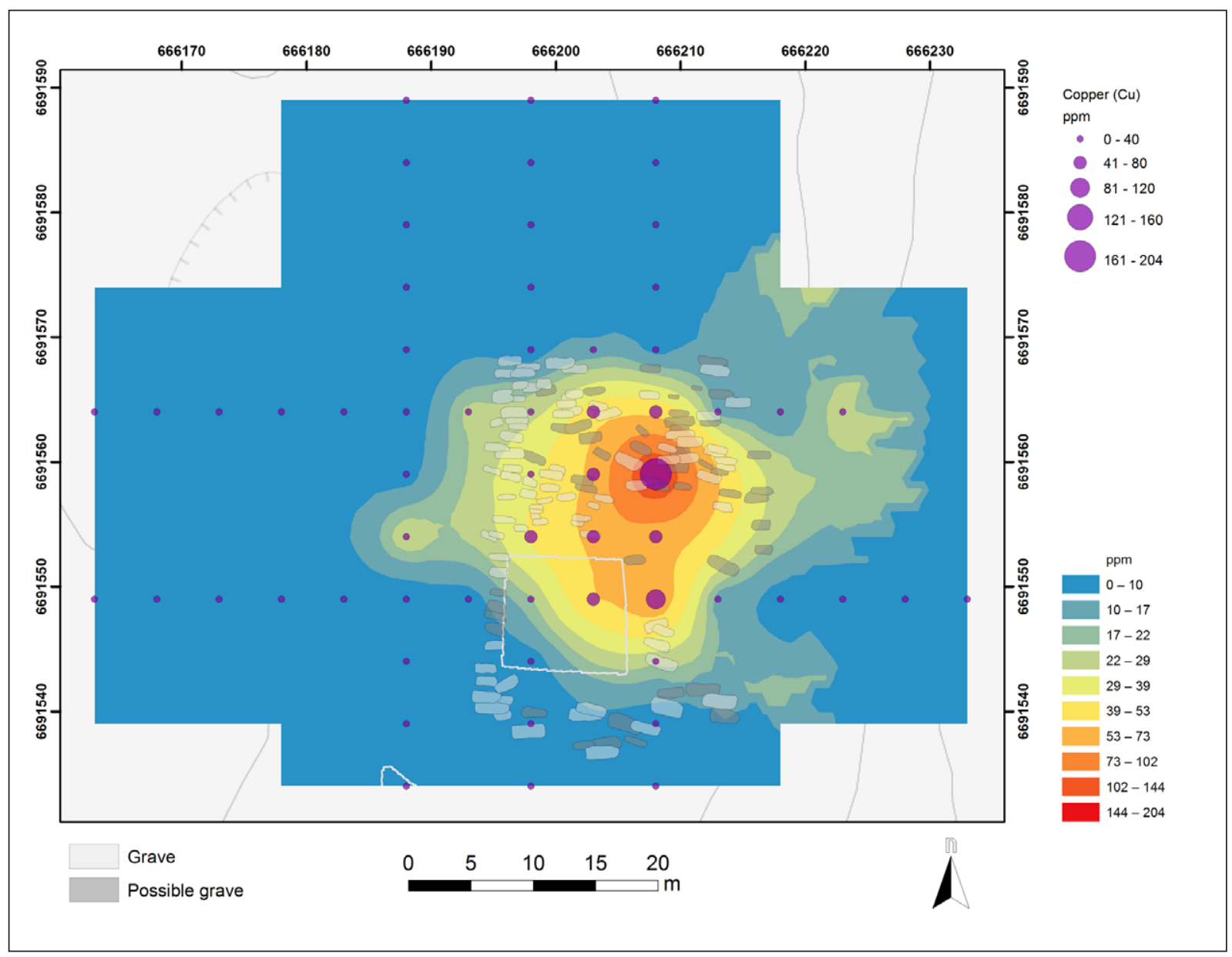

Figure 7: Interpolated distribution of $\mathrm{Cu}$ (ordinary kriging), with the sample points as graduated circles overlaid over the GPR interpretations.

values do not correlate with the area where bones are being ploughed to the surface. It is tentatively suggested that this is the location of the small timber church, which is discussed further below.

One automatically associates calcium with bones; over $70 \%$ of human bone is composed of calcium phosphate crystals (Branca 1997). The measured values range from soil samples was 5,370.63 to 7,287.79 ppm (Figure 8), slightly lower than the background value range of 5,872.68-7,931.46 ppm. These have a similar range, suggesting that there is considerable natural variation in the sediments. The distribution of values in the graveyard area, however, suggests some input from the inhumations. Where the bones are visible on the surface, in the eastern part of the sampled area, the calcium values are consistently higher, reflecting the fact that weathering inputs have contributed to the soil composition. Where the burials remain below the plough depth, to the north and west, the calcium values are consistently lower. Whilst this does not define the graveyard area itself, it does indicate a large proportion of the area has burials disturbed by ploughing and plough erosion.

Phosphate has a long history of association with archaeology as an indicator of past human activity. Besides being present in all organic material, it also is a major component of bone. The background values vary from 422.09-1,239.61 ppm, with the topsoil values being greatly enhanced compared to the subsoil samples. The measured values in the sampled area range from 647.80 to $1,497.08 \mathrm{ppm}$ (Figure 9), with the highest values being concentrated in the central and eastern areas.

The distribution of values shows two central trends: firstly that the central area of the graveyard is enhanced; an area that corresponds to the elevated $\mathrm{Cu}$ values. Secondly, there is a 'halo' of lower values immediately outside the grave area as identified via GPR. To the east this is less clear, however this area has considerable plough erosion. This ring of lower values is potentially archaeologically significant, and is discussed further below.

\section{Discussion and Conclusions \\ Interpreting the GPR dataset}

As is evident from this survey and others elsewhere (e.g., Schneidhofer et al. 2016), GPR data can provide valuable information on environmental setting, both past and present, and allows for a broader contextual interpretation of the site. At Furulund, the data shows that the church site is located atop a series of now backfilled palaeochannels and flood deposits in an area that was once more densely forested than it appears today. In addition, information on modern intrusions such as drainage ditches can be 


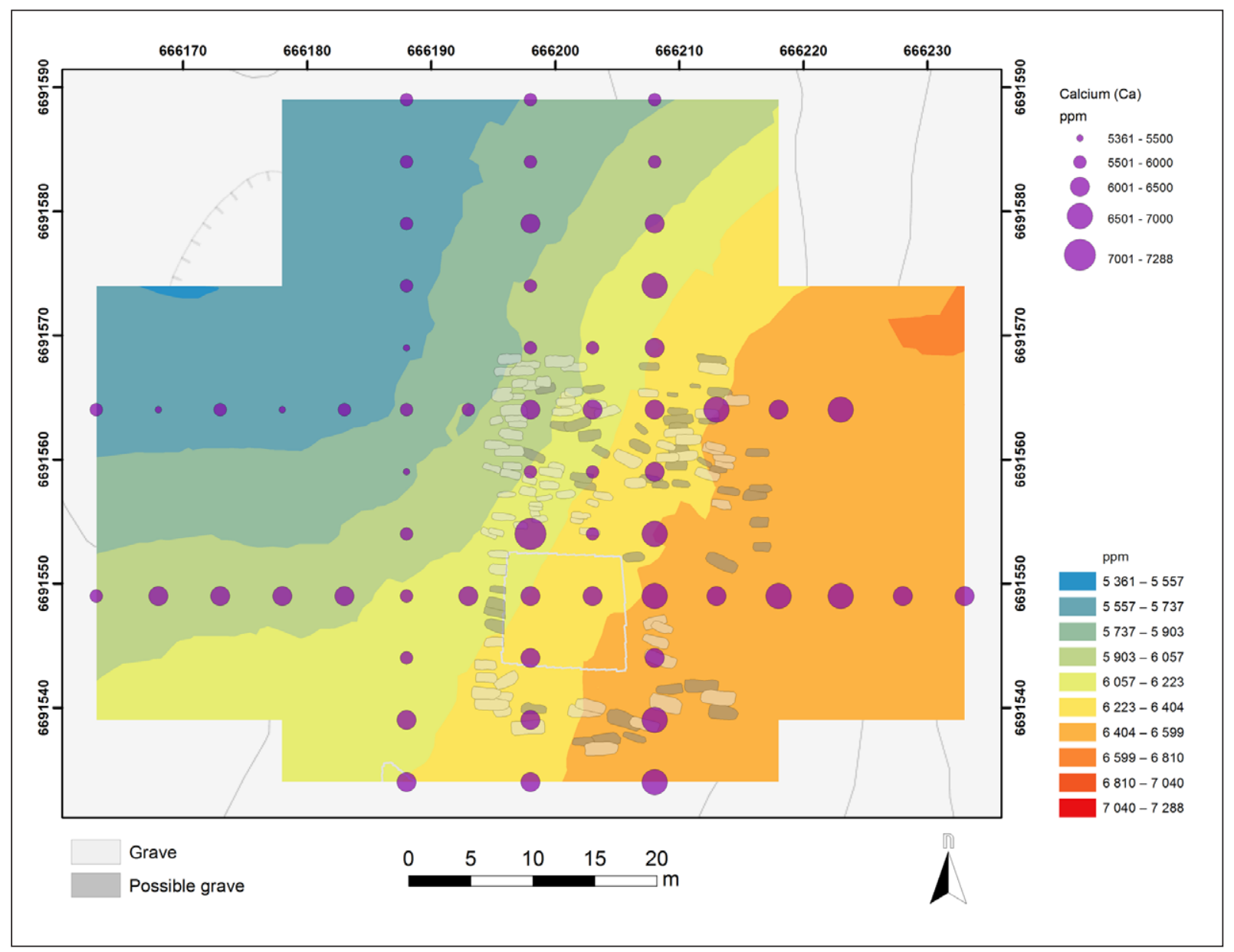

Figure 8: Interpolated distribution of $\mathrm{Ca}$ (ordinary kriging), with the sample points as graduated circles overlaid over the GPR interpretations.

gleaned, as can the extent and degree of erosion on the slope to the east of the graveyard (Figure 10).

The successful mapping of features and deposits in GPR data is to a large degree dependent on the relative proportions of water retained in the soil. In soils where the difference in relative dielectric permittivity (RDP) between layers is low, the radar signal will pass through with little or no reflections generated. Conversely, where the difference in water content, and therefore RDP, is high, and occurs over a short distance, high amplitude reflections will be generated at the interface (Conyers 2012: 34-40). At Furulund, the upper deposits overlying the graveyard appear to form a homogenous, attenuating surface where no archaeological features can be identified. This conflicts with the human remains observed in the topsoil, which again indicates that graves close to the surface are being truncated by ploughing. The first indications of a presence of a graveyard only appear at a depth of c. $60-80 \mathrm{~cm}$, where the surrounding deposits generate relatively high amplitude reflections, while the anomalies representing graves retain low amplitude properties. A working hypothesis for Furulund, therefore, is that the deposits covering the site are fairly homogenous and well-draining, and compositionally identical to the backfill of the graves, hampering a positive identification in the upper parts of the dataset. Below these deposits, the fluvial deposits into which the graves have been cut must be structurally different, presumably retaining more water. This change is fairly abrupt, as the deposits clearly reflect considerably more of the energy in the radar signal. Constructing the original graves has disrupted this reflective surface, and must have altered its water retaining properties. The vertical grave shafts have formed free-draining pockets of soil and, as there is little structural difference between these and the overlying deposits, relatively little energy is reflected compared to the surrounding soil matrix.

The successful detectability of graves in geophysical datasets is inherently linked to the grave's original form and its present state. This, in turn, is governed by cultural factors such as the status of the individual, mortuary traditions or depth of burial, as well as natural conditions such as local pedology, geomorphology and geology (Dick et al. 2017). Inhumation graves should, in theory, be detectable using GPR, particularly at the contact zone between grave shaft and backfill (Conyers 2006: 66), and graves containing surviving coffins should readily lend themselves to detection on account of the presence of voids, or solid remnants of the casket (Conyers 2012). Graves containing bodies simply wrapped in shrouds are naturally harder to detect. Here, the backfill needs to be significantly altered texturally or the grave shaft needs to disrupt the natural stratigraphy in order to create a distinct contrast to the 


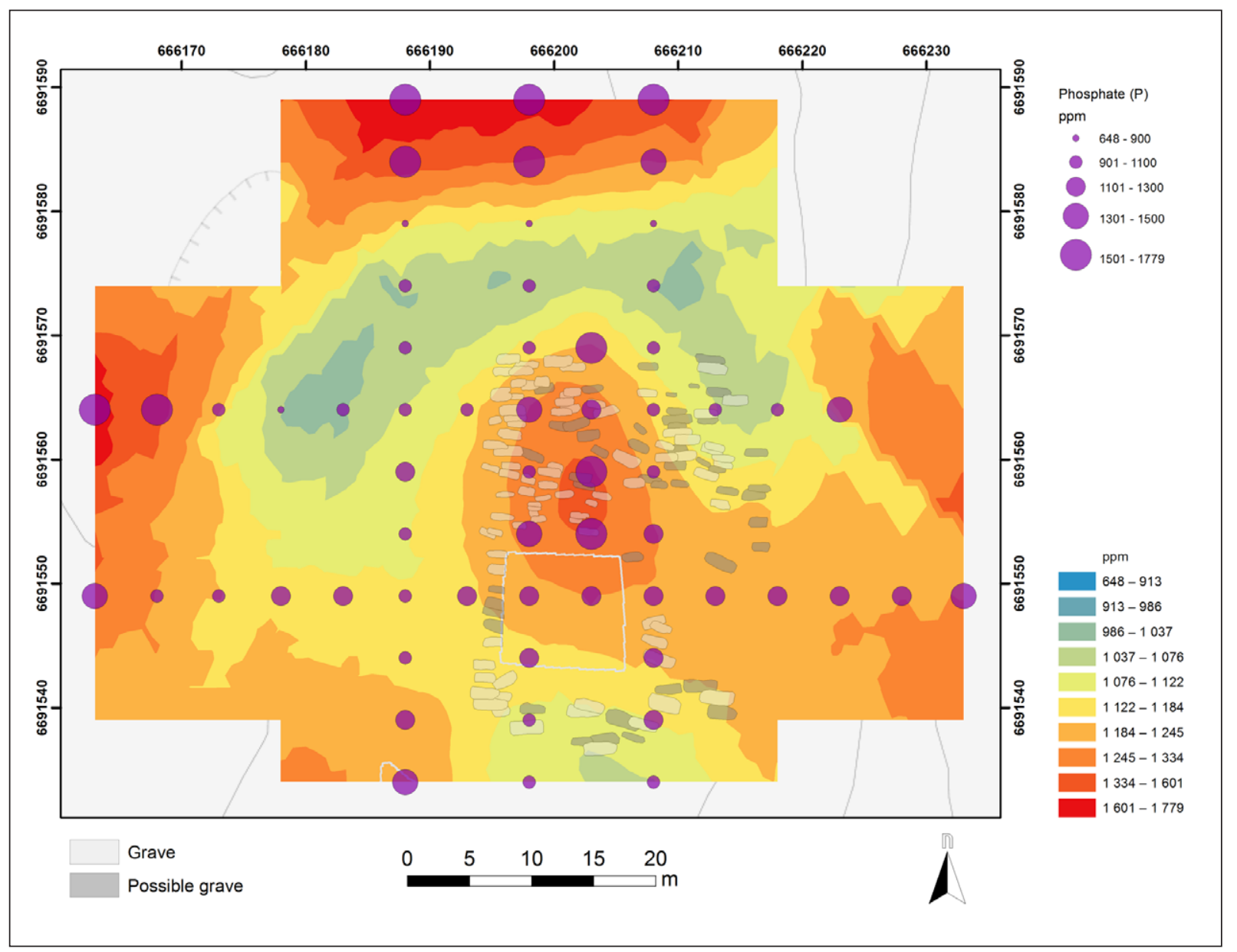

Figure 9: Interpolated distribution of $\mathrm{P}$ (ordinary kriging), with the sample points as graduated circles overlaid over the GPR interpretations.

surrounding soil matrix (Conyers 2006: 70). In literature regarding the detection of graves by means of radar, these are almost invariably recognised and presented as hyperbolic point-source reflections, generated from the top or sides of surviving caskets, from voids created by partially collapsed coffins within the grave (e.g., Conyers 2006: 69), or even by cavities formed by skeletal remains (Damiata et al. 2013). As the graves mapped at Furulund have backfills with low reflection properties, it is perhaps reasonable to assume that the graves were originally without caskets or with simple wrappings such as tree bark. Any such remains will have, due to the present soil conditions, decomposed to such a degree that they are now undetectable. Regardless of the original character of the graves, it is clear that their construction must have altered the natural stratigraphy of the site, thereby altering the local drainage properties.

Although poorly defined as individual features, the graves form a distinct cluster with a relatively clear outline and delineation, making an adjustment of the original interpretation possible. According to the earlier delineation, the graveyard was positioned directly north of the present villa and gardens and, to a degree, encompassing these. It was believed to be semicircular in shape, measuring approximately $36 \mathrm{~m}$ in length $(\mathrm{N}-\mathrm{S})$ and $33 \mathrm{~m}$ in width (E-W). According to our interpretations of the GPR data, however, the graveyard is actually smaller and has a markedly different layout. It measures approximately $32 \mathrm{~m}$ in length, and can be securely traced to a width of $22 \mathrm{~m}$. This tallies well with proportions observed in previously excavated medieval graveyards in Scandinavia (Reitan 2006: 256), although the layout of the Furulund graveyard differs somewhat. The surveys indicate that the graveyard had a rectangular shape, with relatively sharp delineations to the north and west. The eastern boundary is less clear and is damaged by the down-slope erosion, and the southern edge is obscured by modern gardens. It is, however, reasonable to assume that the linear brink of the slope has originally formed the eastern boundary of the graveyard. As for its position, the GPR survey shows that this also differs from the previous interpretation, with a centre point further north than what was previously thought. The GPR survey yielded no trace of solid building remains, neither in terms of foundations or a graveyard demarcation, presumably as a result of the intense cultivation of the area since being converted to agricultural land. Small rural churches in early medieval Norway were exclusively of timber construction supported by posts set in stone lined postholes, or later featuring sill beams resting on stone foundations (Brendalsmo 2015: 105). Neither method leaves much in terms of physical remains 


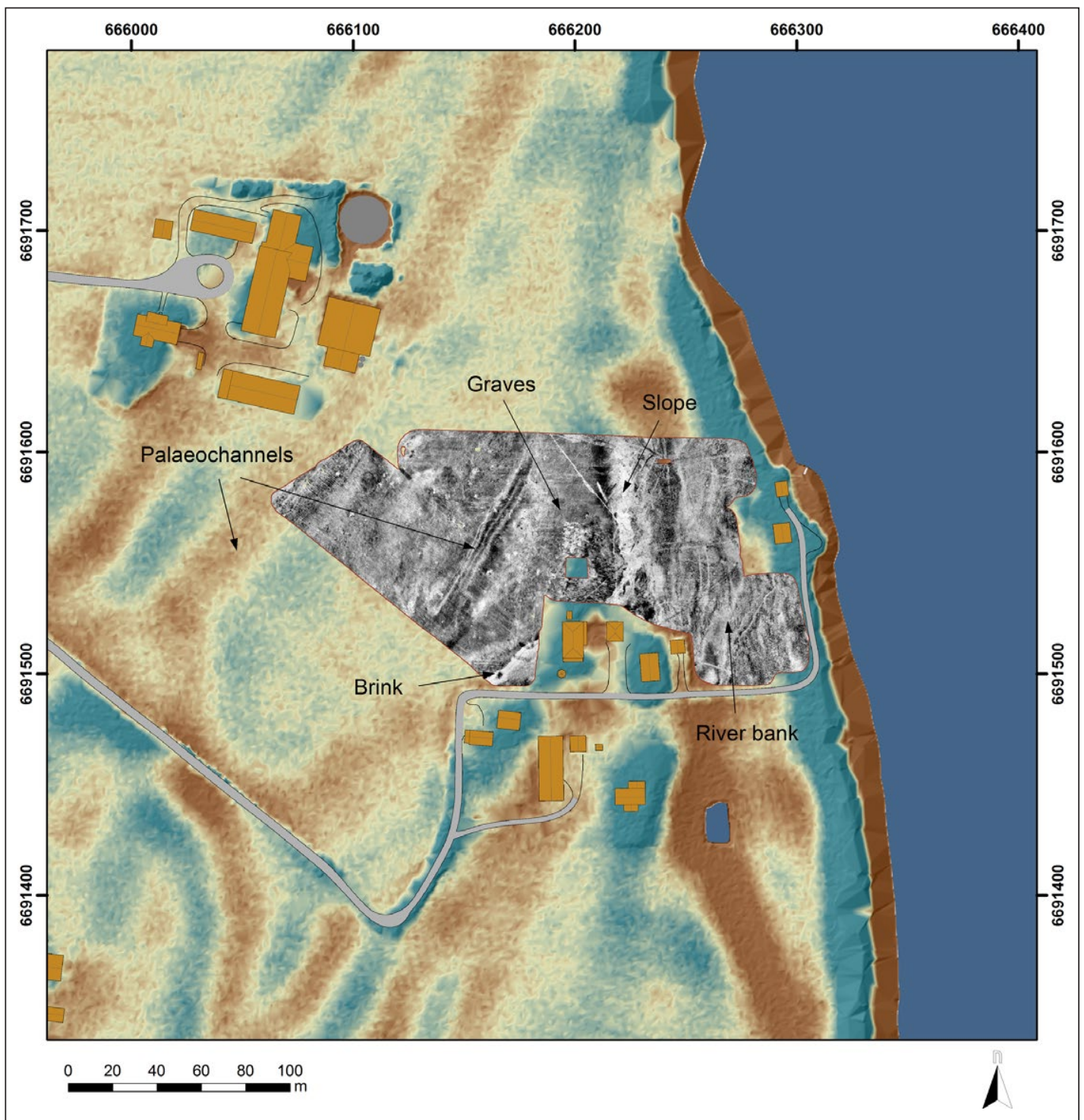

Figure 10: The GPR data provides information on the past and present setting of the church site. Map source: The Norwegian Mapping Authority, Geovekst and Municipalities, 2018.

upon removal, and would be difficult to detect using geophysical methods following centuries of intense ploughing. If, as speculated here, that the enhanced $\mathrm{Cu}$ in the soil is associated with the church location, then the building can be tentatively located fairly centrally to the graveyard area.

\section{Interpreting the geochemical dataset}

In the case of Furulund, the application of archaeological geochemistry was judged to have the potential to detect the long-lasting use of the site for both a church and burials; activity which over several hundred years will have imported objects and human remains to that location. The contrast to the surrounding area, which was probably cultivated or forested but not used for consistent burials, is likely to be marked and measurable from elemental enhancement. The human body contains substantial amounts of calcium, phosphate, iron and other elements in lesser amounts (Bethell \& Smith 1989), and coffins, shrouds or clothing, with or without personal ornamentation, all adds elemental enhancement to the soil within a specified, culturally, ritually and perhaps physically delineated area. The bones, and therefore potentially the enhanced soils, are now beginning to surface, as each time the plough turns the soil, it scrapes the subsoil to a greater or lesser degree, and the elemental enhancement is becoming incorporated into the plough soil. Studies have shown that the movement of objects in the soil, and by implication the soil itself by the plough, is often less than $5 \mathrm{~m}$ from its point of origin (Gustavsen et al. 2017), suggesting that any enhancement will be broadly representative of the graveyard area.

Early sources for Christian law in Norway such as Frostatingsloven, which in part dates to the late eleventh century, state that burial in a church graveyard was both a law and a right, with exceptions such as those who were excommunicated. As consecrated land, graveyard demarcation was necessary and stipulated by law although, as Brendalsmo notes, there are discrepancies 
between early written laws and practice as revealed by archaeological investigations (Brendalsmo 2000). As for the nature of the graveyard demarcation, this could have been an insubstantial construction such as a wooden fence or a simple ditch. According to the early Christian laws of Norway, rural graveyards were traditionally enclosed by wooden fences, the congregation being responsible for its upkeep (Jensenius 2000: 62), and previous excavations of rural medieval church sites have also revealed insubstantial features demarcating the churchyard (Reitan 2006: 256-258, with refs.). If such an enclosure was present at Furulund, its detection by GPR would have depended on its state of preservation and the character of the backfill. Given the soil conditions on site, and the evident truncation of other archaeological features by modern activities, however, it is unlikely to have survived as anything but an area of differentiation in use and thus invisible to GPR. As suggested in the geochemical data for the northern limit of the graveyard in the area of lower P values, particularly to the north and west, we have a possible location of the graveyard boundary, thus the geochemical data adds detail to the GPR results.

That the enhanced $\mathrm{P}$ correlates with the elevated $\mathrm{Cu}$ could suggest that this was the focus of activity in the churchyard, and likely the church itself. No trace of the church is visible in the GPR data, but here the geochemical data may offer insight. Explaining the presence of $\mathrm{Cu}$ is challenging as there are few comparative datasets available, however the church was at the fore of introducing and expanding monetary use in early medieval Norway (1050-1250 A.D.), and encouraged offerings in the church in coin form, a practice that became firmly established by the 1200 's. Large numbers of coins have been found distributed directly under medieval churches, as has been attested by excavation at several medieval churches (Gullbekk 2015: 237-242). The lack of other metals associated with coinage, such as silver, at Furulund, creates interpretative problems although, as this was a meagre, local church, the wealth of the congregation was perhaps limited to offering lower value coins. It should also be noted that evidence of fine smithing (bronze ingots, crucible fragments, globules) has been observed on at least one near contemporary church site (Reitan 2006). Here, fragments of bronze, tentatively interpreted as book fittings, were also found within the limits of the church itself. Given the proliferation of coins found on medieval church sites elsewhere it seems reasonable that the increased $\mathrm{Cu}$ values at Furulund represent coin deposition rather than the, so far, rarely observed smithing activity.

\section{Methodological assessment}

Methodologically, the surveys at Furulund have yielded valuable information on the feasibility of using GPR and soil chemical techniques for the delineation of graveyards containing inhumation graves on cultivated land.

In the process of sampling, mapping, selecting and interpreting, it must always be acknowledged the inherent bias in the process. These are caused by a plethora of issues, some more openly or easily addressed than others. On the technical side, we have the instrument parameters, detection limits, internal and empirical calibration performed, and also the sampling limitations. For example, sampling the base of the topsoil assumes a constant and even scouring of the plough into the subsoil, and even amalgamation of this material into the base of the topsoil. This is obviously not always the case, nor the assumption that any artificial or natural fertilisers used over the site have a universal and even effect. Element selection is in part based on our reliance on previous studies for reference and how the data is handled via interpolative techniques. Of course, the success of the technique is firmly established via published material, but this does not mean that each individual case study should ignore the ever present bias in the data produced. A further complication in geochemical analysis is the local environmental conditions which cannot, and should not, be compared wholesale to other case studies (Oonk, Slomp \& Huisman 2009; Bethell \& Smith 1989). The use of pXRF as an analytical instrument is also a source of error due to issues of sample heterogeneity, surface geometry, instrument resolution that varies per element, and issues of signal interference and peak overlap (Schneider et al. 2016; Cannell 2017). Whilst sample pre-treatment and drying can mitigate some of these issues, for pXRF the final data set is a proportional representation of the actual amounts in the sample, on a per-element basis. The data does not represent absolute values. As interpretation is always based on intra-site relative enhancement and considered contextually, this was deemed as suitable to answer the aims of the project. Future application of the method to similar sites will test if these elements can be established as more universal indicators of medieval settlement and burial. Despite these limitations in the use of pXRF, the data has produced valuable and interpretable data that adds further dimensions to the site use and extent when combined with the GPR data.

The GPR survey has demonstrated that it is possible to identify individual graves and clusters of graves, given that the present soil conditions are favourable. As observed at Furulund, the topmost $60 \mathrm{~cm}$ of the dataset covering the graveyard are all but void of archaeological features, whilst human remains are continually being brought to the surface by the plough. This indicates that, while graves are probably present fairly close to the surface, the geophysical contrast between these and the upper deposits is too low to produce identifiable anomalies. The cause of this lack of contrast is at present not known, but could be related to the current ploughing regime at the site, where the graves are decimated to such a degree that they are unlikely to be identified even using traditional methods such as topsoil stripping. It could, however, also be related to the original construction of the graves where they have been backfilled using material compositionally identical to that of the surrounding soils. The successful identification of graves at Furulund only occurs at 
depth where the deposits are more likely to retain water and where the construction of graves has disturbed the natural stratigraphy. This has formed pockets of welldrained soil which contrasts with the surrounding soil matrix. Given the particular soil conditions at Furulund, therefore, it is not possible to evaluate the potential of GPR on its own on sites of similar date and character but with set in areas with completely different soil conditions.

Overall, therefore, the combination of techniques can be used to mitigate individual weaknesses, and enhance the overall interpretation. Here, the GPR response was poor for the upper depth range due to environmental factors, whereas the geochemical data is a surface technique dependent on the site truncation by ploughing. GPR provided an insight into the composition, density and layout of the graveyard, whereas the geochemical data provided information on the location of the graveyard boundary, and the presence and potential activities within the church. The damage to the east of the site is present in both datasets, but the geochemical data, using $\mathrm{Ca}$ from bone, suggests the extent of it. Together, therefore, they create a more nuanced picture of the previous site use and current state, in a minimally/non-intrusive manner.

\section{Acknowledgements}

The authors are indebted to Ingunn Dahlseng Håkonsen and Live Johannessen and at the Norwegian Directorate for Cultural Heritage, for instigating the geophysical survey at Furulund. The geochemical analyses were funded in their entirety by the Techno-SIS programme at NIKU, and we would like to extend our gratitude to project manager Ole Risbøl for diverting the necessary funds to carry out the survey and analyses. Finally, we wish to thank Jan Brendalsmo at NIKU for his valuable input and for sharing his extensive knowledge on medieval church sites in Norway.

\section{References}

Ammerman, A J 1985 Plow-Zone Experiments in Calabria, Italy. Journal of Field Archaeology, 12(1): 33-40. DOI: https://doi.org/10.1179/009346985 791169544

Aston, M, Martin, M and Jackson, A 1998 The use of heavy metal soil analysis for archaeological surveying. Chemosphere, 37: 465-477. DOI: https:// doi.org/10.1016/S0045-6535(98)00062-9

Åstveit, L I 2008 Lokalitet 50 Søndre Steghaugen. In: Bjerk, H B (ed.), Ormen Lange Nyhamna, 267-284. Trondheim: Tapir forlag.

Bakkevig, S 1980 Phosphate Analysis in Archaeology. Problems and Recent Progress. Norwegian Archaeological Review, 13(2): 73-100. DOI: https:// doi.org/10.1080/00293652.1980.9965334

Bastos, R O, Melquiades, F L and Biasi, G E V 2012 Correction for the effect of soil moisture on in situ $\mathrm{XRF}$ analysis using low-energy background. X-Ray Spectrometry, 41(5): 304-307. DOI: https://doi. org/10.1002/xrs.2397
Berger, M, Zou, L and Schliecher, R 2009 Analysis of sulfur in the copper basin and muddy river sites. International Journal of Soil, Sediment and Water, 2(3): Article 1.

Bethell, P H and Smith, J U 1989 Trace-element analysis of an inhumation from Sutton Hoo, using inductively coupled plasma emission spectrometry: An evaluation of the technique applied to analysis of organic residues. Journal of Archaeological Science, 16: 47-55. DOI: https://doi. org/10.1016/0305-4403(89)90055-1

Bevan, B W 1991 The search for graves. Geophysics, 56(9): 1310-1319. DOI: https://doi.org/10.1190/ 1.1443152

Bigman, D 2012 The Use of Electromagnetic Induction in Locating Graves and Mapping Cemeteries: an Example from Native North America. Archaeological Prospection, 19: 31-39. DOI: https://doi.org/ 10.1002/arp.1416

Bigman, D 2014 Mapping social relationships: Geophysical survey of a nineteenth-century American slave cemetery. Archaeological and Anthropological Sciences, 6: 17-30. DOI: https://doi.org/10.1007/ s12520-013-0119-6

Bissett, T G and Claassen, C P 2016 Portable x-ray fluorescence in sourcing prehistoric whelk shell artifacts. North American Archaeologist, 37(3): 143-169. DOI: https://doi.org/10.1177/ 0197693116631675

Booth, A D, Vandeginste, V, Pike, D, Abbey, R, Clark, R A, Green, C M and Howland, N 2017 Geochemical insight during archaeological geophysical exploration through in situ X-ray fluorescence spectrometry. Archaeological Prospection, Online preview. DOI: https://doi.org/10.1002/arp.1575

Branca, F 1997 Calcium, micronutrients and physical activity to maximize bone mass during growth. In: Albert, J L, Ciaffi-Cannizzo, L, Lupien, J R, Randell, A, Malek, Z, Cotier, J P, Clay, W D, Orriss, D and Menza, $\mathrm{V}$ (eds.), Food, Nutrition and Agriculture. Rome, Italy: FAO Information Division.

Brendalsmo, J 1989 Peterskirken, dens kirkegård og det eldste Tønsberg. Tønsberg: Riksantikvaren.

Brendalsmo, J 2000 De dødes landskap: måtte man begraves ved sognekirken i middelalderen? Hikuin, 27: $27-42$.

Brendalsmo, J 2014 Gildeskål kirkegård. In: Stige, $\mathrm{M}$ and Ekroll, $\varnothing$ (eds.), Gildeskål gamle kirke: Marmorkirka ved nordvegen, 75-96. Bergen: Fagbokforlaget.

Brendalsmo, J 2015 Middelalderske kirkesteder i Hedmark fylke. Oslo: Riksantikvaren.

Brendalsmo, J and Eriksson, J-E G 2015 De middelalderske sakrale stedene. In: Johannessen, L and Eriksson, J-E G (eds.), Faglig program for middelalderarkeologi: Byer, sakrale steder, befestninger og borger, 97-138. Oslo: Riksantikvaren.

Cannell, R J S 2017 Prospecting the Physicochemical Past. Three dimensional geochemical investigation into the use of space in Viking Age sites in 
southern Norway using portable XRF. PhD-thesis. Bournemouth University.

Canti, M 2003 Aspects of the chemical and microscopic characteristics of plant ashes found in archaeological soils. Catena, 54: 339-361. DOI: https://doi.org/ 10.1016/S0341-8162(03)00127-9

Carey, C J, Wickstead, H J, Juleff, G, Anderson, J C and Barber, M J 2014 Geochemical survey and metalworking: Analysis of chemical residues derived from experimental non-ferrous metallurgical processes in a reconstructed roundhouse. Journal of Archaeological Science, 49: 383-397. DOI: https:// doi.org/10.1016/j.jas.2014.05.017

Charlton, M F 2013 Handheld XRF for Art and Archaeology (Studies in Archaeological Sciences 3). Journal of Archaeological Science, 40(7): 3058-3059. DOI: https://doi.org/10.1016/j.jas.2013.03.001

Cheetham, P 2005 Forensic Geophysical Survey. In: Hunter, J and Cox, M (eds.), Forensic Archaeology: Advances in Theory and Practice, 62-95. London: Routledge.

Conyers, L B 2006 Ground-Penetrating Radar Techniques to Discover and Map Historic Graves. Historical Archaeology, 40(3): 64-73. DOI: https://doi.org/ 10.1007/BF03376733

Conyers, L B 2012 Interpreting Ground-penetrating Radar for Archaeology. Walnut Creek, CA: Left Coast Press Inc.

Cook, S F and Heizer, R F 1965 Studies on the Chemical Analysis of Archaeological Sites. University of California Publications in Anthropology, 2: 1-102.

Cook, S R, Banerjea, R Y, Marshall, L, Fulford, M, Clarke, A and Van Zwieten, C 2009 Concentrations of copper, zinc and lead as indicators of hearth usage at the Roman town of Calleva Atrebatum (Silchester, Hampshire, UK). Journal of Archaeological Science, 37(4): 871-879. DOI: https://doi.org/10.1016/j.jas.2009.11.017

Coronel, E G, Bair, D A, Brown, C T and Terry, R E 2014 Utility and Limitations of Portable X-Ray Fluorescence and Field Laboratory Conditions on the Geochemical Analysis of Soils and Floors at Areas of Known Human Activities. Soil Science, 179(5): 258-271. DOI: https://doi.org/10.1097/ SS.0000000000000067

Dalan, R A, De Vore, S L and Clay, R B 2010 Geophysical identification of unmarked historic graves. Geoarchaeology, 25(5): 572-601. DOI: https://doi. org/10.1002/gea.20325

Damiata, B N, Steinberg, J M, Bolender, D J and Zoëga, G 2013 Imaging skeletal remains with groundpenetrating radar: Comparative results over two graves from Viking Age and Medieval churchyards on the Stóra-Seyla farm, northern Iceland. Journal of Archaeological Science, 40(1): 268-278. DOI: https://doi.org/10.1016/j.jas.2012.06.031

Davenport, G C 2001 Remote Sensing Applications in Forensic Investigations. Historical Archaeology, 35(1): 87-100. DOI: https://doi.org/10.1007/ BF03374530
Davis, J L, Heginbottom, J A, Annan, A P, Daniels, R, Berdal, B P, Bergan, T, Duncan, K E, Lewin, P K, Oxford, J S, Roberts, N, Skehel, J J and Smith, C R 2000 Ground Penetrating Radar Surveys to Locate 1918 Spanish Flu Victims in Permafrost. Journal of Forensic Sciences, 45(1): 68-76. DOI: https://doi. org/10.1520/JFS14642J

Dick, H C, Pringle, J K, Wisniewski, K D, Goodwin, J, Putten, R V D, Evans, G T, Francis, J D, Cassella, J P and Hansen, J D 2017 Determining Geophysical Responses from Burials in Graveyards and Cemeteries. Geophysics, 82(6): B245-B255. DOI: https://doi.org/10.1190/geo2016 $-0440.1$

Donais, M K and George, D 2012 Using Portable XRF to Aid in Phasing, Locus Comparisons, and Material Homogeneity Assessment at an Archaeological Excavation. In: Shugar, A and Mass, J (eds.), Handheld $X R F$ in Art and Archaeology, 349-378. Leuven: Leuven University Press.

Drasch, G A 1982 Lead burden in prehistorical, historical and modern human bones. Science of The Total Environment, 24(3): 199-231. DOI: https://doi.org/ 10.1016/0048-9697(82)90001-8

Entwistle, J A, Abrahams, $\mathbf{P} \mathbf{W}$ and Dodgshon, $\mathbf{R}$ A 1998 Multi-Element Analysis of Soils from Scottish Historical Sites. Interpreting Land-Use History Through the Physical and Geochemical Analysis of Soil. Journal of Archaeological Science, 25(1): 53-68. DOI: https://doi.org/10.1006/ jasc.1997.0199

Fleisher, J and Sulas, F 2015 Deciphering public spaces in urban contexts: Geophysical survey, multielement soil analysis, and artifact distributions at the 15th-16th-century AD Swahili settlement of Songo Mnara, Tanzania. Journal of Archaeological Science, 55: 55-70. DOI: https://doi.org/10.1016/j. jas.2014.12.020

Frahm, E and Doonan, R C P 2013 The technological versus methodological revolution of portable XRF in archaeology. Journal of Archaeological Science, 40(2): 1425-1434. DOI: https://doi.org/10.1016/j. jas.2012.10.013

Gauss, R K, Bátora, J, Nowaczinski, E, Rassmann, Kand Schukraft, G 2013 The Early Bronze Age settlement of Fidvár, Vráble (Slovakia): reconstructing prehistoric settlement patterns using portable XRF. Journal of Archaeological Science, 40(7): 2942-2960. DOI: https://doi.org/10.1016/j.jas.2013.01.029

Gjerpe, L E and Samdal, M 2005 Fosfatkartering, georadar og magnetismemåling. In: Gjerpe, L E (ed.), Gravfeltet på Gulli, 152-160. Oslo: Kulturhistorisk museum, UiO.

Grattan, J P, Gilbertson, D D, Waller, J H and Adams, R B 2014 The geoarchaeology of "waste heaps" from the ancient mining and beneficiation of copper-rich ores in the Wadi Khalid in southern Jordan. Journal of Archaeological Science, 46: 428-433. DOI: https://doi.org/10.1016/j. jas.2013.08.001 
Gullbekk, S H 2015 The Church and Money in Norway c. 1050-1250: Salvation and Monetisation. In: Gullbekk, S H and Gasper, G E M (eds.), Money and the Church in Medieval Europe, 1000-1200. Practice, Morality and Thought, 223-243. Farnham: Ashgate.

Gustavsen, L 2014 Archaeological Geophysics in Norwegian Funerary Archaeology. In: Sellevold, B J (ed.), Old Bones - Osteoarchaeology in Norway: Yesterday, Today and Tomorrow, 261-278. Oslo: Novus Forlag.

Gustavsen, L, Kristiansen, M, Nau, E and Tafjord, B-E 2017 Assessing the Effect of Modern Ploughing Practices on Archaeological Remains by Combining Geophysical Surveys and Systematic Metal Detecting. 12th International Conference of Archaeological Prospection, 98-99. Archaeopress.

Hayes, K 2013 Parameters in the use of pXRF for archaeological site prospection: A case study at the Reaume Fort Site, Central Minnesota. Journal of Archaeological Science, 40(8): 3193-3211. DOI: https://doi.org/10.1016/j.jas.2013.04.008

Jensenius, J H 2000 Hvorfor ble kirkegårder velsignet? Hikuin, 27: 57-66.

Jones, G 2008 Geophysical Mapping of Historic Cemeteries. Technical Briefs in Historical Archaeology, 3: 25-38.

Kalnicky, D J and Singhvi, R 2001 Field portable XRF analysis of environmental samples. Journal of Hazardous Materials, 83(1-2): 93-122. DOI: https:// doi.org/10.1016/S0304-3894(00)00330-7

Keeley, H C M, Hudson, G E and Evans, J 1977 Trace element contents of human bones in various states of preservation 1. The soil silhouette. Journal of Archaeological Science, 4: 19-24. DOI: https://doi. org/10.1016/0305-4403(77)90109-1

Linford, N T 2004 Magnetic Ghosts: Mineral Magnetic Measurements on Roman and Anglo-Saxon Graves. Archaeological Prospection, 11: 167-180. DOI: https://doi.org/10.1002/arp.232

Middleton, W D 2004 Identifying Chemical Activity Residues on Prehistoric House Floors: AMethodology And Rationale For Multi-Elemental Characterization of a Mild Acid Extract of Anthropogenic Sediments. Archaeometry, 46(1): 47-65. DOI: https://doi. org/10.1111/j.1475-4754.2004.00143.x

Moffat, I 2015 Locating Graves with Geophysics. In: Sarris, A (ed.), Best Practices of Geoinformatic Technologies for the Mapping of Archaeolandscapes, 45-53. Oxford: Achaeopress.

NGU 2017 Database for losmassegeologi. Available at: http://geo.ngu.no/kart/losmasse/ [Last accessed 5 November 2017].

NIBIO 2017 Kilden. Available at: https://kilden.nibio.no/ [Last accessed 5 November 2017].

Nobes, D C 1999 Geophysical Surveys of Burial Sites: A Case Study of the Oaro Urupa. Geophysics, 64(2): 357-367. DOI: https://doi.org/10.1190/1.1444540

Norwegian Mapping Authority Topografisk norgeskart 3. Scale Not Given. January 31, 2018 https://wms. geonorge.no/skwms1/wms.topo3?request=GetCap abilities\&service=WMS (February 12, 2018).
Oonk, S, Slomp, C P and Huisman, DJ 2009 Geochemistry as an aid in archaeological prospection and site interpretation: Current issues and research directions. Archaeological Prospection, 16: 35-51. DOI: https://doi.org/10.1002/arp.344

Oonk, S, Slomp, C P, Huisman, D J and Vriend, S P 2009 Effects of site lithology on geochemical signatures of human occupation in archaeological house plans in the Netherlands. Journal of Archaeological Science, 36(6): 1215-1228. DOI: https://doi.org/10.1016/j. jas.2009.01.010

Parsons, C, Margui Grabulosa, E, Pili, E, Floor, G H, Roman-Ross, G and Charlet, L 2012 Quantification of trace arsenic in soils by field-portable X-ray fluorescence spectrometry: Considerations for sample preparation and measurement conditions. Journal of Hazardous Materials, 262: 1213-1222. DOI: https://doi.org/10.1016/j.jhazmat.2012.07.001

Photos-Jones, E and Hall, A J 2011 Archaeological recording and chemical stratigraphy applied to contaminated land studies. Science of The Total Environment, 409(24): 5432-5443. DOI: https:// doi.org/10.1016/j.scitotenv.2011.08.035

Price, T D, Burton, J H and Bentley, R A 2002 The Characterization of Biologically Available Strontium Isotope Ratios for the Study of Prehistoric Migration. Archaeometry, 44(1): 117-135. DOI: https://doi. org/10.1111/1475-4754.00047

Prøsch-Danielsen, L 1996 Forsandmoen i Rogaland arkeologi og naturvitenskap avdekker bosetning og kulturlandskap gjennom 2000 år. Jord og gjerning, 36-49. Årbok for Norsk Landbruksmuseum 1994/95.

Prøsch-Danielsen, L 2005 Historisk riss av utvikling og integrering av arkeologiske og naturvitenskapelige metoder. Eksempler fra Forsand og Rogaland forøviig. AMS Varia 43, 15-27.

Provan, D 1973 The soils of an Iron Age farm site -bjellandsøynæ, SW Norway. Norwegian Archaeological Review, 6: 30-41. DOI: https://doi. org/10.1080/00293652.1973.9965180

Provan, D M J 1971 Soil phosphate analysis as a tool in archaeology. Norwegian Archaeological Review, 4: 37-50. DOI: https://doi.org/10.1080/00293652.1 971.9965134

Reitan, G 2006 Faret i Skien - en kristen gravplass fra vikingtid og nye innblikk i tidlig kirkearkitektur. Viking, 251-274. LXIX.

Schneider, A, Cancès, B, Breton, C, Ponthieu, M, Morvan, X, Conreux, A and Marin, B 2016 Comparison of field portable XRF and aqua regia/ICPAES soil analysis and evaluation of soil moisture influence on FPXRF results. Journal of Soils and Sediments, 16(2): 438-448. DOI: https:// doi.org/10.1007/s11368-015-1252-x

Schneidhofer, P, Nau, E, Hinterleitner, A, Lugmayr, A, Bill, J, Gansum, T, Paasche, K, Seren, S, Neubauer, W, Draganits, E and Trinks, I 2016 Palaeoenvironmental analysis of large-scale, highresolution GPR and magnetometry data sets: The Viking Age site of Gokstad in Norway. Archaeological 
and Anthropological Sciences, 9(6): 1187-1213. DOI: https://doi.org/10.1007/s12520-015-0312-x

Schneidhofer, P, Nau, E, Leigh Mcgraw, J, Tonning, C, Draganits, E, Gustavsen, L, Trinks, I, Filzwieser, R, Aldrian, L, Gansum, T, Bill, J, Neubauer, W and Paasche, K 2017 Geoarchaeological evaluation of ground penetrating radar and magnetometry surveys at the Iron Age burial mound Rom in Norway. Archaeological Prospection, 1-17. DOI: https://doi.org/10.1002/arp.1579

Shackley, M S (ed.) 2011 X-Ray Fluoresence Spectrometry $(X R F)$ in Geoarchaeology, New York: Springer. DOI: https://doi.org/10.1007/978-1-4419-6886-9

Solli, B and Stamnes, A A 2013 Geofysiske undersøkelser av kirkegårder, kirketufter og svartjord på Veøy i Romsdalen. Viking, 181-202. LXXVI.

Speakman, R J and Shackley, S M 2013 Silo science and portable XRF in archaeology: A response to Frahm. Journal of Archaeological Science, 40(2): 1435-1443. DOI: https://doi.org/10.1016/j.jas.2012.09.033

Trinks, I, Gansum, T and Hinterleitner, A 2010 Mapping iron-age graves in Norway using magnetic and GPR prospection. Antiquity, 84(326, Project gallery).
Ulmanu, M, Anger, I, Gamenț, E, Mihalache, M, Plopeanu, G and Ilie, L 2011 Rapid determination of some heavy metals in soil using an x-ray fluorescence portable instrument. Research Journal of Agricultural Science, 43(3): 235-241.

Vaughan, C J 1986 Ground-penetrating radar surveys used in archaeological investigations. Geophysics, 51(3): 595-604. DOI: https://doi. org/10.1190/1.1442114

Vyncke, K, Waelkens, M, Degryse, P and Vassilieva, E 2011 Identifying domestic functional areas. Chemical analysis of floor sediments at the Classical-Hellenistic settlement at Düzen Tepe (SW Turkey). Journal of Archaeological Science, 38(9): 2274-2292. DOI: https://doi.org/10.1016/j. jas.2011.03.034

Wilson, C A, Davidson, D A and Cresser, M S 2009 An evaluation of the site specificity of soil elemental signatures for identifying and interpreting former functional areas. Journal of Archaeological Science, 36(10): 2327-2334. DOI: https://doi.org/10.1016/j. jas.2009.06.022

How to cite this article: Cannell, R J S, Gustavsen, L, Kristiansen, M and Nau, E (2018). Delineating an Unmarked Graveyard by High-Resolution GPR and pXRF Prospection: The Medieval Church Site of Furulund in Norway. Journal of Computer Applications in Archaeology, 1(1), pp. 1-18, DOl: https://doi.org/10.5334/jcaa.9

Submitted: 17 November $2017 \quad$ Accepted: 01 February $2018 \quad$ Published: 19 March 2018

Copyright: (c) 2018 The Author(s). This is an open-access article distributed under the terms of the Creative Commons Attribution 4.0 International License (CC-BY 4.0), which permits unrestricted use, distribution, and reproduction in any medium, provided the original author and source are credited. See http://creativecommons.org/licenses/by/4.0/.

] J J Journal of Computer Applications in Archaeology, is a peer-reviewed open access journal published by Ubiquity Press.

OPEN ACCESS $\precsim$ 